support to this assumption. For papain digest we have assumed that the active fragments are the same as those produced by reduction of peptic digest ${ }^{3}$ and that the proportion of radioactivity absorbable is the same as that in the whole (before dialysis) peptic digest of the $7 \mathrm{~S}$ preparation.

Comparisons have been made of the $7 S$ antibody (separated by DEAE-cellulose chromatography) and its derivatives from three rabbits, all the derivatives from one serum being investigated simultaneously. In each case, the curves for $7 S$ antibody and peptic digest have been almost identical. The curves for univalent fragments, however derived, have been very close together and parallel. The concentrations of $A_{1}$ cells necessary to absorb half the antibody from $7 S$ or $5 S$ preparations from each of the three rabbits were, respectively, $0 \cdot 16$, 0.03 and 0.02 per cent; the cell concentrations required to absorb half the univalent antibody derived from these preparations were, respectively, 19, 10.5 and 6 per cent. That is to say $\frac{K \text { bivalent } A b(7 S \text { or } 5 S)}{K \text { univalent } A b \text { fragments }}$ was 119,350 and 300 respectively for the threo rabbit sera.

The greatly diminished binding constant of univalent antibody fragments could be explained if the process of splitting the molecule had distorted the antibody specific group; this seems unlikely since, at least for a small hapten, $K$ remains unaltered after splitting the antibody molecule ${ }^{5}$; moreover, if the binding constant of antibody sites were drastically diminished it seems improbable that a comparatively small excess of univalent fragments would inhibit precipitation in the ovalbumin-anti-ovalbumin system ${ }^{2}$. Labelling with iodine does not appear harmful since labelled anti-ovalbumin fragments which we have prepared inhibit precipitation in the same proportion as described by Porter. It is possible that reduction in the size per se of the antibody would reduce $K$ by eliminating some non-specific binding of the antibody molecule, but we find no difference in $K$ between the $7 S$ and the bivalent $5 S$ fragment derived therefrom.

We consider that the great diminution in binding constant which accompanies the reduction of antibody valency from 2 to 1 gives support to our hypothesis that rabbit immune $7 S$ anti- $A$ antibody mostly combines with the red cell by both its specific groups. The possibility of this type of antigen-antibody attachment does not appear to have received consideration and is even excluded from his calculations by Goldberg ${ }^{6}$, although it is not necessary to postulate that the bivalent attachment of antibody on a red cell is to a single antigen molecule. However, Almeida, Cinader and Howatson ${ }^{2}$ have shown electron micrographs which may be interpreted as bivalent attachment of a single antibody molecule to a wart virus particle.

A final resolution of this point may be possible by the examination, which we are about to attempt, of univalent fragments recombined to the bivalent $5 S$ form $^{8}$, where if our hypothesis is correct, recombined pure antibody should regain its $5 S$ binding constant, whereas $5 S$ recombinants made up of one antibody and one non-antibody $3.5 \mathrm{~S}$ fragment would have the binding constant of a univalent fragment.

${ }^{1}$ Grcenbury, C. L., Moore, D. H., and Nunn, L. A. C., Immunol., 6, 42 (1963). ${ }^{2}$ Porter, R. R., Biochem. J., 73, 119 (1959).

${ }^{3}$ Nisonoff, A., Wissler, F. C., Lipman, L. N., and Woernler, D. L., Arch. Biochem. Biophys., 89, 230 (1960).

4 Fudenberg, H., Mandy, W. J., and Nisonoff, A., J. Clin. Invest., 41, 2123 (1962).

s Nisonoff, A., and Woernley, D. L., Nature, 188, 1325 (1959).

- Goldberg, R. J., J. Amer. Chem. Soc., 74, 5715 (1952).

${ }^{7}$ Almeida, J., Cinader, B., and Howatson, A., J. Exp. Med., 118, 327 (1963).

${ }^{8}$ Mandy, W. J., Rivers, M. M., and Nisonoff, A., J. Biol. Chem., 236, 3221 (1961).

\title{
QUINACILLIN : A COMPARISON WITH OTHER PENICILLINASE-RESISTANT PENICILLINS
}

\author{
By Dr. J. T. SMITH, Dr. J. M. T. HAMILTON-MILLER and Prof. R. KNOX \\ Department of Bacteriology, Guy's Hospital Medical School, London, S.E.I
}

\begin{abstract}
$\mathrm{Q}$ UINACILLIN, 3-carboxy-2-quinoxalinylpenicillin, a recently described semi-synthetic penicillin, was found ${ }^{1}$ to have 'unusual properties', namely, antibacterial activity highest against Staphylococcus aureus, enhancement of antibacterial activity and rate of diffusion in agar with decrease in $p \mathrm{H}$ of the medium, and poor inducing ability for staphylococcal penicillinase. In view of these findings, we have examined the interactions of quinacillin with various bacteria and their penicillinases, and are able to confirm and extend the description of this penicillin as possessing "unusual properties".

Quinacillin as a substrate for penicillinase. (a) Grampositive bacteria. The rates of hydrolysis of quinacillin at various concentrations in $0.025 \mathrm{M}$ sodium phosphate buffer $p H \quad 7.4$ were measured using the hydroxylamine method $^{2}$. With staphylococcal penicillinase made, as previously described ${ }^{3}$, from Staph. aureus E3, the Michaelis constant $\left(K_{m}\right)$ for quinacillin was $61 \mathrm{mM}$ $\left(28 \mathrm{mg} / \mathrm{ml}\right.$.) with a $V_{\max } 8$ per cent that of benzylpenicillin; at an initial concentration of $4.3 \mathrm{mM}(2 \mathrm{mg} / \mathrm{ml}$.) quinacillin was not appreciably hydrolysed by this preparation. Richards et al. ${ }^{1}$, who used the iodometric method of assay at $p \mathbf{H} 6 \cdot 5$, found that the $K_{m}$ value for staphylococcal penicillinase (Parker strain) was $5 \mathrm{mg} / \mathrm{ml}$. and the $V_{\max }$ was 5 per cent that of benzylpenicillin. They also found no appreciable hydrolysis of quinacillin at lower concentrations.
\end{abstract}

Penicillinase preparations ${ }^{4}$ from $B$. cereus and $B$. licheniformis were found to hydrolyse quinacillin (initial concentration $4.3 \mathrm{mM}$ ) at 11 and 13 per cent, respectively, of the rates at which they hydrolysed benzylpenicillin. Both these preparations had $K_{m}$ values for quinacillin of about $54 \mathrm{mM}$.

(b) Gram-negative bacteria. Cell-free preparations made from $P r$. morgani $G$ (ref. 5), Pr. rettgeri $410, K$. aerogenes 366 (ref. 6) and $E$. coli $214 T$ (ref. 7) did not appreciably hydrolyso quinacillin (initial concentration $4.3 \mathrm{mM}$ ). A cell-free extract of $A$. cloacae 53 (ref. 6) hydrolysed quinacillin $(4.3 \mathrm{mM})$ at about 7 per cent of the rate at which it destroyed benzylpenicillin $(5.4 \mathrm{mM})$ and intact cells of this organism hydrolysed quinacillin at about one-seventh of this rate (Table l). Disruption of this strain has been shown ${ }^{6}$ to increase its hydrolytic activity towards berzylpenicillin 25 times. Thus it seems that quinacillin can pass the substrate accessibility barrier in this strain more readily than benzylpenicillin.

Quinacillin as an antibacterial agent. Minimum inhibitory concentrations of quinacillin were determined, by means of the tube test, for six strains of Staph. aureus, $E 3,13137,6637,5974$ (all of which produce penicillinase, the last three being resistant to methicillin and cloxacillin $^{8}$ ), $E 3 T$ and Oxford (benzylpenicillin-sensitive, penicillinase-negative strains). Two inoculum sizes were used, about $10^{6}$ and about $10^{2}$ viable units per tube. The results

Table 1. Destruction of 2 Penicimins BY A. cloacae 53 (rates expressed as $\mu \mathrm{g} / \mathrm{min} / 10^{\circ}$ cells $/ \mathrm{ml}$.) Intact Disrupted $\begin{aligned} & \text { Ratio (to nearest whole number) of } \\ & \text { penicillinase activity of disrupted to }\end{aligned}$ cells cells intact cells ( = 'permeability factor') $\begin{array}{lrrr}\text { Quinacillin } & 3 & 20 & 7 \\ \text { Benzylpenicillin } & 12 & 303 & 25\end{array}$ 
Table 2. ANTIBACTERIAL ACTIVITY OF QUINACILIIN AGAINS' SIX STRATNS OF Staph. aureus Minimum inhibitory concentrations ( $\mu \mathrm{g} / \mathrm{ml}$.)

\begin{tabular}{|c|c|c|c|c|c|c|c|}
\hline \multirow{2}{*}{\multicolumn{2}{|c|}{$\begin{array}{l}\text { Penicillin } \\
\text { Inoculum }\end{array}$}} & \multicolumn{2}{|c|}{ Methicillin } & \multicolumn{2}{|c|}{ Cloxacillin } & \multicolumn{2}{|c|}{ Quinacillin } \\
\hline & & $10^{8}$ & $10^{2}$ & $10^{6}$ & $10^{2}$ & $10^{6}$ & $10^{2}$ \\
\hline 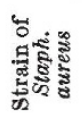 & $\begin{array}{l}E 3 \\
13137 \\
6637 \\
5974 \\
E 3 T \\
\text { Oxford }\end{array}$ & $\begin{array}{r}7 \cdot 5 \\
1,000 \cdot 0 \\
>1,000 \cdot 0 \\
500 \cdot 0 \\
3 \cdot 2 \\
1 \cdot 6\end{array}$ & $\begin{array}{r}3 \cdot 7 \\
125 \cdot 0 \\
25 \cdot 0 \\
100 \cdot 0 \\
1.6 \\
0.8\end{array}$ & $\begin{array}{r}5 \cdot 0 \\
500 \cdot 0 \\
1,000 \cdot 0 \\
1,000 \cdot 0 \\
0 \cdot 8 \\
0 \cdot 4\end{array}$ & $\begin{array}{l}1 \cdot 0 \\
5 \cdot 0 \\
5 \cdot 0 \\
5 \cdot 0 \\
0 \cdot 4 \\
0 \cdot 2\end{array}$ & $\begin{array}{r}6 \cdot 3 \\
50 \cdot 0 \\
400 \cdot 0 \\
25 \cdot 0 \\
6 \cdot 3 \\
6 \cdot 3\end{array}$ & $\begin{array}{r}3 \cdot 1 \\
12 \cdot 5 \\
6 \cdot 3 \\
6 \cdot 3 \\
6 \cdot 3 \\
1 \cdot 6\end{array}$ \\
\hline
\end{tabular}

Table 3. Minimum InHibitory Concentrations of Quinacilinin, TESTED agaINST Gram-NEGATIVE BaCTERIA BY TUBE DLUTION METHOD Inoculum size approximately $10^{\circ}$ organisms

$\begin{array}{lr}K \text {. aerogenes } 83,370,415,418 & >4,000 \\ \boldsymbol{K} \text {. aerogenes } 1,43,366,373,407,414 & >8,000 \\ \boldsymbol{K} \text {. ozaenae } 61 & >4,000 \\ \boldsymbol{E} \text {. coli } 214 \mathrm{~T} & >2,000 \\ \text { Pr. morgani } \mathrm{G} & 680 \\ \text { Pr. rettgeri } 410 & >2,000 \\ \text { Achromobacter } 510 & 500 \\ \text { A. cloacae } 53 & 4,000 \\ \text {. } & >20,000\end{array}$

Table 4. Inducing Abilttifas of Four Compounds for Penicmininase of Staph. aureus E3

\begin{tabular}{|c|c|c|c|}
\hline & $\begin{array}{l}\text { Concentration } \\
\mu \mathrm{g} / \mathrm{ml} \text {. } \\
\text { to give maximal } \\
\text { induction }\end{array}$ & $\begin{array}{l}\mu \mathrm{g} / \mathrm{ml} \text {. to give } \\
\text { half maximal } \\
\text { induction }\end{array}$ & $\begin{array}{l}\text { Ratio of induced } \\
\text { to basal penicil- } \\
\text { linase activity } \\
\text { at maximum }\end{array}$ \\
\hline $\begin{array}{l}\text { Quinacillin } \\
\text { 6-Aminopenicillanic }\end{array}$ & $12 \cdot 5$ & $2 \cdot 07$ & $17 \cdot 8$ \\
\hline $\begin{array}{l}\text { acid * } \\
\text { Methicillin * } \\
\text { Cloxacillin } †\end{array}$ & $\begin{array}{r}10 \cdot 0 \\
3 \cdot 0 \\
0 \cdot 1\end{array}$ & $\begin{array}{l}3 \cdot 0 \\
0 \cdot 27 \\
0 \cdot 013\end{array}$ & $\begin{array}{l}16 \cdot 3 \\
36 \cdot 0 \\
71 \cdot 3\end{array}$ \\
\hline & * Ref. 3. & f. 15 . & \\
\hline
\end{tabular}

(Table 2) show that there is cross-resistance between cloxacillin, methicillin and quinacillin, but it appears that resistant strains are slightly more susceptible to quinacillin than to the other two, at least using large inocula. 'The 'inoculum size effect' obtained with this series of organisms is probably a reflexion of populations that are not homogeneous, in that they contain small proportions of highly resistant bacteria". In common with other penicillins, quinacillin was extremely poor at inhibiting the growth of $B$. cereus, the minimum inhibitory concentration being $5 \mathrm{mg} / \mathrm{ml}$. for an inoculum of $10^{6}$ organisms. Quinacillin was relatively inactive as an antibacterial agent against Gram-negative bacteria (Table 3). Richards et $a l .{ }^{1}$ also found that Gram-negative bacteria were resistant to quinacillin.

Quinacillin as an inducing agent for penicillinases. The ability of quinacillin to induce penicillinase production in Staph. aureus E3 was determined as described previously ${ }^{3}$ and the results arc shown in Table 4 . It can be seen that the concentrations for half maximal induction ('induction constants'10) with quinacillin, mothicillin and cloxacillin were $2.07,0.27$ and $0.013 \mu \mathrm{g} / \mathrm{ml}$, respectively. 'Thus the 'induction constant' for quinacillin is some eight times larger than that for methicillin and 160 times larger than that for cloxacillin. In addition, as judged by the concentrations required for maximal induction and by the amount of enzyme production at these concentrations, quinacillin was a less effective inducing agent than either methicillin or cloxacillin. Using the Parker strain of Staph. aureus, Richards et al. ${ }^{1}$ reported a twenty-five-fold difference between the 'induction constants' for methicillin and quinacillin, so, allowing for strain differences, it soems that quinacillin is a much poorer inducing agent than would be expected from its activity against penicillinase-producing staphylococci.

It appeared that the figures obtained horc for quinacillin in induction experiments were very similar to those found for 6-aminopenicillanic acid in an earlier scries of experiments ${ }^{3}$. To determine whether quinacillin was broken down to 6-aminopenicillanic acid (which could explain these similarities) during the process of induction, quinacillin was incubated at $37^{\circ} \mathrm{C}$ with washed cells from an overnight culture of $E 3$ in phosphate-buffered saline at $p \mathrm{H} 7.4$ for $3 \mathrm{~h}$. The cells were centrifuged down, and enough of the supernatant fraction to contain approximately $50 \mu \mathrm{g}$ quinacillin was applied to Whatman No. 1 paper and chromatographed in $n$-butanol $4:$ acetic acid 1 : water 5, descending overnight; markers of quinacillin, the penicilloic acid derived from it (made by dissolving quinacillin in $\mathrm{N}$ soda, and neutralizing with $\mathrm{N}$ hydrochloric acid after 30 min at room temperature) and 6 -aminopenicillanic acid were also applied to the chromatogram. When the run had been completed, the paper was dipped in 0.2 per cent ninhydrin in acetone ${ }^{11}$, heated for 5 min at $100^{\circ} \mathrm{C}$ and then 'fixed' in alcoholic copper nitrate. Under these conditions, the quinacillin developed a palcyellow colour, fluorescent in ultra-violet light (this yellow fluorescence could also be observed before ninhydrin treatment). The penicilloic acid developed a red colour which did not fluoresce. The $R_{P}$ values of these two compounds in the solvent used were 0.82 and 0.65 , respectively. No trace of a spot similar to that derived from 6-aminopenicillanic acid $\left(R_{F}\right.$ value 0.53 - which develops a golden-yellow colour, slightly fluorescent ${ }^{11}$ ) could be observed in the incubation mixture. Nor was any evidence of a penicillin acylase obtained when the butyl acetato extraction technique ${ }^{12}$ was used, with benzylpenicillin as substrate, with this strain of Staph. aureus. Hence, it appears that the resemblance between the values of certain induction parameters of quinacillin and 6-aminopenicillanic acid is a mere coincidence.

Quinacillin, benzylpenicillin, methicillin, cloxacillin and 6-aminopenicillanic acid were tested for inducing ability towards the penicillinase of $B$. cereus. Various concentrations of each inducing agent were dissolved in broth, $2 \mathrm{ml}$. of a $6-\mathrm{h} 37^{\circ} \mathrm{C}$ culture of $B$. cereus 569 added to each $100 \mathrm{ml}$, and bottles woro incubated overmight at $37^{\circ} \mathrm{C}$. Portions were centrifuged $(3,000 \mathrm{~g}$ for $15 \mathrm{~min})$, after $\mathrm{mM}$ $p$-chlormercuribenzoate had been added to prevent further induction, and the turbidity measured at $700 \mathrm{~m} \mu$. The supernatant fraction was adjusted to $p H \quad 7 \cdot 4$ with $N$ sodium hydroxide and the rate of hydrolysis of benzylpenicillin estimated by the hydroxylamine method. Results were exprossed in terms of the amount of increase in penicillinase activity as compared with a control culture grown in broth alone; Table 5 shows the results obtained. It is clear that quinacillin, although a better inducing agent than benzylpenicillin (probably duo to its greater stability to this penicillinase), is not so efficient at the higher concentration as methicillin, cloxacillin or 6-aminopenicillanic acid.

Quinacillin did not cause any increased enzyme production in five strains of $K$. aerogenes-43, 370, 373, 407 and 414 nor in $K$. ozaenae 61 ; this is in common with the non-inducibility of these penicillinases by all other compounds tested ${ }^{6}$. When Pr. morgani 185 (ref. 5) and Pr. rettgeri 410 vere grown overnight at $37^{\circ} \mathrm{C}$ in the presence of half the minimum inhibitory concentration of quinacillin, penicillinase was induced. The activities of these cultures after disruption, expressed in terms of $\mu \mathrm{g}$ benzylpenicillin hydrolysed $/ \mathrm{min} / 10^{8}$ cells $/ \mathrm{ml}$., were 5.6 and $3 \cdot 7$, respectively. Uninduced preparations of these two organisms hydrolysed less than $0.1 \mu \mathrm{g}$ benzylpenicillin/ $\mathrm{min} / 10^{9} \mathrm{cell} / \mathrm{ml}$.

Quinacillin as an inhibitor of benzylpenicillin hydrolysis by penicillinases. Penicillins which are only slowly hydrolysed by penicillinases have been shown to inhibit benzylpenicillin hydrolysis by $B$. cereus ${ }^{13}, B$. licheniformis ${ }^{11}$, $K$. aerogenes ${ }^{14}, \boldsymbol{E}$. coli ${ }^{14}$ and $\operatorname{Pr}$. morgani $i^{14}$ penicillinase preparations. Mixtures of $1.3 \mathrm{mM}(0.5 \mathrm{mg} / \mathrm{ml}$.) benzylpenicillin and $\mathrm{mM}$ quinacillin were incubated with enzyme

\begin{tabular}{|c|c|c|}
\hline & \multicolumn{2}{|c|}{$\begin{array}{l}\text { Ratio of concentration of inducing agent } \\
\text { to minimum inhibitory concentration for } \\
\text { that inducing agent }\end{array}$} \\
\hline & $1 / 10$ & $1 / 4$ \\
\hline Benzylpenicillin $(1,250)$ & 9 & 7 \\
\hline Quinacillin $(5,000)$ & 31 & 39 \\
\hline oxacillin (500) & 21 & 54 \\
\hline -Aminopenicillanic acid $(10,000)$ & 66 & 92 \\
\hline Methicillin (313) & 25 & 140 \\
\hline
\end{tabular}

Figures in brackets are minimum inhibitory concentrations of drugs for B. cereus (large inoculum, in $\mu \mathrm{g} / \mathrm{ml}$.).

Figures in body of the Table are enzymatic aeitivity after induction, taking basal level $=1$. 
preparations from Staph. aureus E3, B. cereus 569 and $B$. licheniformis, which had been odjusted to hydrolyse $2 \mu \mathrm{g}$ benzylpenicillin/min ${ }^{11,15}$. The rates of hydrolysis in the presence of quinacillin, measured by the hydroxylamine method, were compared with those obtained in the absence of quinacillin but no differences were observed. Hence, quinacillin, in contrast to the other poorly hydrolysed penicillins, does not inhibit any of the penicillinase preparations from Gram-positive bacteria examined.

When cell-free penicillinase preparations of $E$. coli $214 T$ and $\mathrm{Pr}$. morgani $\mathrm{G}$ were tested by the modified spectrophotometric method ${ }^{11}$, no inhibition of the hydrolysis of benzylponicillin $(2.7 \mathrm{mM})$ could be detected in the presence of concentrations of quinacillin as high as $260 \mu \mathrm{M}$. However, under similar conditions 50 per cent inhibition of the penicillinase activities of $K$. aerogenes 366 and 373 was observed with $70 \mu \mathrm{M}$ and $161 \mu \mathrm{M}$ quinacillin, respectively; thus, quinacillin is about as active an inhibitor of the Klebsiella penicillinases as oxacillin and $B R L 1577$ (ref. 14). The fact that quinacillin does not inhibit the $E$. coli and Proteus penicillinase preparations is in contrast to the inhibitory action of other penicillins stable to the penicillinases of these bacteria.

Discussion. Richards et $a .^{1}{ }^{1}$ found that quinacillin possessed unusual properties. We have confirmed that this pənicillin is a poor inducing agent for staphylococcal penicillinase, and in addition we have shown that it is a ralatively inefficient inducer of $B$. cereus penicillinase.

As a substrate for penicillinases derived from various sources, quinacillin shows in general a marked resistance to hydrolysis; its affinity for staphylococcal and Bacillus penicillinases was uniformly low, but it was hydrolysed rather more rapidly by the Bacillus enzymes. Penicillinase preparations from $K$. aerogenes, $E$. coli and $P r$. morgani did not detectably destroy the compound, although a strain of $A$. cloacce did hydrolyse quinacillin. An interesting feature of this penicillin is that it does not inhibit penicillinases from $B$. cereus and $B$. licheniformis, which is in contrast to the action of other poorly hydrolysed penicillins. Similarly, penicillinase preparations from $E$. coli and $\mathrm{Pr}$. morgani were not inhibited by quinacillin, and it was found to be only a very weak inhibitor of $K$. aerogenes penicillinases.

The discovery that a penicillin which is a poor inducer of staphylococcal penicillinase can also be an effective antistaphylococeal agent discounts the correlation that has been made by some authors ${ }^{15-18}$ between inducing ability and antibacterial activity for penicillinase-producing staphylococci. Until now penicillins which are biologically active against penicillinase-producing Staph. aureus, besides being resistant to hydrolysis by this enzyme, have also been found to be very good inducing agents and can markedly inhibit various penicillinases. It is interesting that although quinacillin does possess the first two characteristics it is not a particularly good inducing agent nor an efficient inhibitor of penicillinases.

We thank Boots Pure Drug Company, Ltd., for gifts of quinacillin.

1 Richards, H. C., Housley, J. R., and Spooner, D. F., Nature, 199, 354 (1963). Spooner, D. F., and Spicer, A. B., J. Gen. Microbiol., 33, 7 (1963). 2 Boxer, G. E., and Everett, P. M., Anal. Chem., 21, 670 (1949).

${ }^{3}$ Knox, R., and Smith, J. T., J. Gen. Microbiol., 28, 471 (1962).

4 Smith, J. T., and Hamilton-Miller, J. M. T., Nature, 197, 769 (1963).

${ }^{5}$ Hamilton-Miller, J. M. T., Biochem. Biophys. Res. Comm., 13, 43 (1963).

- Smith, J. T., and Hamilton-Miller, J. M. T., Nature, 197, 976 (1963).

' Smith, J. T., J. Gen. Microbiol., 30, 299 (1963).

${ }^{8} \mathrm{Knox}, \mathrm{R}$., and Smith, J. T., Brit. Med. J., ii, 205 (1963).

- Knox, R., and Smith, J. T., Lancet, ii, 520 (1961).

${ }^{10}$ Pollock, M. R., Biochem. J., 66, 419 (1957).

1 Hamilton-Miller, J. M. T., Biochem. J., 87, 209 (1963).

${ }^{2}$ Batchelor, F. R., Chain, E. B., and Rolinson, G. N., Proc. Roy. Soc., B., 154, 478 (1961).

13 Citri, N., and Garber, N., J. Pharm. Pharmacol., 14, 784 (1962)

14 Hamilton-Miller, J. M. T., and Smith, J. T., Nature, 201, 999 (1964).

${ }^{15}$ Smith, J. T., Hamilton-Miller, J. M. T., and Knox, R., Nature, 195, 1300 (1962).

${ }^{16}$ Knox, R., Nature, 192, 492 (1961).

${ }^{17}$ Crompton, B., Jago, M., Crawford, K., Newton, G. G. F., and Abraham, $\mathrm{E}, \mathbf{P}$, Biochem $J, \mathbf{8 3}, 52(1962)$.

${ }_{18}$ Pollock, M. R., Ciba Found. Study Group, 13, 56 (1962).

\title{
A COMPARISON OF EFFECTS OF SOME CHEMOTHERAPEUTIC AGENTS AND THOSE OF X-RAYS ON THE REPRODUCTIVE CAPACITY OF MAMMALIAN CELLS
}

\author{
BY DR. ROGER J. BERRY* \\ Radiobiology Laboratory, Radiotherapy Department, Churchill Hospital, Oxford
}

$\mathrm{W}$ HILE chemotherapeutic agents have been extensively investigated for ability to 'cure' a wide range of transplanted tumours in vivo ${ }^{1}$ and have less frequently been investigated qualitatively in vitro in cultures of mam. malian cells ${ }^{2}$, there has been a paucity of quantitative investigation of the effect on cell reproductive capacity of agents known to have clinical usefulness in palliation of human cancer ${ }^{3,4}$. The technique of clonal cell culture described by Puck et al. ${ }^{5}$ by which macroscopically visible colonies can be grown in vitro from single mammalian cells has been extensively applied to the examination of effects of ionizing radiation (see Porter ${ }^{6}$ for a representa. tive list of references). It is only recently, however, that this method has been used to investigate the dose-response to a chemotherapeutic agent?

The present communication reports investigations of the dose-response relationship for the reproductive capacity of two strains of mammalian cells exposed in vitro to several commonly used anticancer drugs and compares these relationships with that for $\mathrm{X}$-irradiation of the samo cells.

The drugs used in these experiments were of the following types: (1) Nitrogen mustard. (a) 'HN3' (tri-(2. chloroethyl)-amine, 'Trillekamin', Crookes). (b) Mannitol

* Helen Hay Whitney Fellow in Radiobiology, University of Oxford. mustard (Mannomustine dihydrochloride, 'Degranol', Chinon). (2) Ethylene imine ('Thio-TEPA', Lederle). (3) Epoxide ('Epodyl', I.C.I., 32865). (4) Antimetabolite (5-fluorouracil, Roche). All drugs were diluted with sterile normal saline to desired final concentrations immediately prior to addition to the growth medium.

The mammalian cell lines used were HeLa $S-3_{\text {oxf, }}$, an aneuploid derivative of human cervical carcinoma kindly supplied by Dr. C. E. Ford, Medical Research Council, Harwell, and re-cloned in this laboratory, and the mouse strain $L_{0 x f}$. fibroblast kindly provided by Dr. J. Paul, Department of Biochemistry, Glasgow, and re-cloned in this laboratory by Dr. A. H. W. Nias. They were grown in Medium 199 (Glaxo) supplemented with $5 \mu \mathrm{g} / \mathrm{ml}$. amphotericin $B$ ('Fungizone', Squibb), and for HeLa: 10 or 20 per cent freshly drawn human AB serum; for strain $L: 2$ per cent pooled ealf serum (Oxoid) and 0.5 per cent 'Bacto-Peptone' (Difco) for stock growth and 10 per cent pooled calf serum for clonal growth.

The technique of clonal culture was modified only slightly from that of Puck et al. ${ }^{5}$; cells were trypsinized ('Bacto-Trypsin', Difco, 0.25 per cent in 0.3 per cent sodium citrate made isotonic with sodium chloride) from a stock bottle containing a nearly confluent sheet of cells. They were re-suspended in the appropriate medium and 